\title{
Promoting educational innovations and change through networks between higher education teachers
}

\author{
Elena Stasewitsch ${ }^{1}$ D $\cdot$ Sofia Dokuka ${ }^{2} \cdot$ Simone Kauffeld $^{1}$
}

Received: 10 February 2021 / Accepted: 26 November 2021 / Published online: 22 December 2021

(c) The Author(s) 2021

\begin{abstract}
Innovation in higher education teaching is essential to respond to global challenges and actively improve teaching (e.g. through new technologies), necessitating the implementation of educational reform programmes that fund educational innovations. Although currently deployed strategies frequently promote networks between innovators to diffuse educational innovations, little is known about the efficiency of these networks or whether they promote innovation diffusion. This study investigates a network comprising 88 higher education teachers who received funding for their educational innovations in a German university. We collected longitudinal data by asking higher education teachers from whom they adopted innovative teaching ideas and requesting self-reports on innovative teaching climate. Our findings show that the teachers' social network had a smaller path length and more clustering than might be expected by chance. This observation might indicate that the examined educational innovation network exhibits a small-world property and allows efficient exchange of ideas among the teachers. In line with our hypotheses, the network's initial tendency toward hierarchy and homophily decreased over time in response to strategies and network interventions. In summary, this study provides initial empirical support that educational reform programmes can create efficient educational innovation networks, facilitating innovation diffusion and promoting change in higher education teaching.
\end{abstract}

Keywords Diffusion of innovation - Educational innovation - Innovative teaching climate · Innovative teaching project $\cdot$ Small-world $\cdot$ Social network analysis

\section{Introduction}

Worldwide, scholars in educational systems have long discussed the need for change and innovation in higher education (Bruckmann \& Carvalho, 2018; Clark, 1968; Kozma, 1985). Due to higher education's societal role, various educational reform programmes have facilitated change

Elena Stasewitsch

e.stasewitsch@tu-braunschweig.de

1 Department of Industrial/Organizational and Social Psychology, TU Braunschweig,

Spielmannstr.19, 38106 Braunschweig, Germany

2 Institute of Education, HSE University, Moscow, Russia 
processes in higher education to enhance teaching quality and support change through educational innovations. Such innovations have involved new projects or programmes aiming to change attitudes, ideas, cultures or pedagogical practices (Kauffeld et al., 2019a; Benz-Gydat et al., 2021; Civis et al., 2019; Fullan, 2010; Jütte et al., 2017). These endeavours have focused on improving teaching at different levels (e.g., the course, programme, or system level; see Hasanefendic et al., 2017) and enhancing student learning (e.g. Kauffeld et al., 2019a, Feixas et al., 2018).

While significant financial and human resources have been deployed to develop and implement educational innovations (Kauffeld \& Othmer, 2019; Benz-Gydat et al., 2021; Hannan et al., 1999; Jütte et al., 2017), some scholars have described educational innovations as "difficult, technically and emotionally demanding as well as complex" (Towndrow et al., 2010, p. 451). Consequently, the question arises as to whether educational innovations can lead to change in higher education teaching.

One approach to creating change via educational innovations is through "networks of educational innovation" (Feixas et al., 2018, p. 2), where higher education teachers can share knowledge or support regarding their educational innovations and larger-scale adoption can take place (Kauffeld et al., 2019a). These networks do not occur naturally and must be strategically constructed (Portes, 1998). Hence, educational reform programmes often employ various strategies to support such networks (e.g. de Lima, 2010; Kezar, 2014), including networking events, training, or teaching conferences, which can help create professional communities between higher education teachers and can be defined as network interventions (Kauffeld et al., 2019a; Benz-Gydat et al., 2021; Gast et al., 2017; Jütte et al., 2017; Van Waes et al., 2018).

Although researchers have suggested that educational innovation networks positively influence higher education teaching, the supporting empirical evidence is scanty. Some scholars have even argued that educational networks supported and developed through reform efforts might operate in a limited, narrow, and goal-directed way, inhibiting innovation diffusion (de Lima, 2010). However, others have found that innovators' characteristics in higher education teaching, such as their strategic use of networks, provide advantages when implementing educational innovations (Hasanefendic et al., 2017). Nevertheless, few studies have examined the structure of educational (innovation) networks in higher education that support knowledge transfer and innovation diffusion (Al-Kurdi et al., 2018; Kezar, 2014). More research is needed to reveal how the characteristics of higher education teachers influence network structures (Hasanefendic et al., 2017).

This study explores the structure of educational innovation networks funded by educational reform programmes and supported via network interventions. Thus, we analysed how educational innovations can efficiently diffuse in these networks, (1) determining how higher education teachers share ideas from their educational innovations in educational innovation networks and (2) investigating what affects the networks' structure. To achieve our goals, we used social network analysis (SNA) to focus on a specific educational innovation network promoted by an educational reform programme.

\section{Theoretical Background}

According to the diffusion of innovation theory (Rogers, 1995), an innovation's adoption rate is influenced by the social system in which it is diffused. The peer network and its structure are crucial to achieving a critical mass of adopters, leading most people in a 
social system to adopt an innovation (Rogers, 1995). In line with Rogers' theory (1995), educational evaluation frameworks propose scaling educational innovations' success by analysing diffusion and adoption processes in social networks (Cohen \& Ball, 2007). This approach has not escaped criticism, as the diffusion of educational innovation on a larger scale is not always intended (or possible) and is rarely observed empirically (Towndrow et al., 2010). At the same time, this approach suggests that detected diffusion processes are a strong indicator of teaching-related change.

Furthermore, these ideas indicate that some network structures are more beneficial for innovation diffusion than others. Organisational research has revealed that the efficiency of network structures for innovation diffusion differs depending on such factors as the network type (e.g. inter-organisational vs intra-organisational networks) or network perspective (e.g. ego-networks vs whole networks; Phelps et al., 2012). Hence, analysing social networks in their respective contexts is necessary to gain a better understanding of innovation diffusion processes (Wolfe, 1994).

Innovation models (Amabile, 1988; Martins \& Terblanche, 2003; Rogers, 1995) describe innovation as a process ranging from development through implementation to its transfer. Various organisational members can be involved at different stages of the process. In the context of innovations in higher education, the network under investigation should incorporate higher education teachers involved in educational innovations. Especially interesting are teachers who focus on educational innovations, e.g., because they receive funding to develop and implement educational innovations. Focusing on innovation diffusion as a means to scale educational innovations implies that network ties between the actors consist of exchange relationships regarding these innovations (e.g. exchanging ideas about educational innovations).

Furthermore, innovation diffusion cannot be sufficiently analysed on an ego network level, which only provides information concerning the individual's social connections (Prell, 2012) and excludes data from a larger social context. The ties between actors in such networks and most actor characteristics can only be assessed indirectly. Hence, this study adopted a whole network approach to analyse the structure of higher education teachers' educational innovation networks. This analytical strategy aligns with other educational studies on innovation and change, for example, analysing departmental networks in higher education (e.g. Quardokus \& Henderson, 2015; see also Authors et al., in press).

\section{The structure of educational innovation networks}

Network centralisation in education has evaded scrutiny, offering excellent possibilities for explaining the flow of knowledge and information in terms of power locations (de Lima, 2010). Analysing a network's centralisation can facilitate drawing conclusions about its social hierarchy. In an educational innovation context, network hierarchy implies that some higher education teachers gain crucial knowledge regarding educational innovations from peers while not sharing ideas and knowledge (to the same extent) themselves.

Teachers in academic departments tend to form clubs or groups (Quardokus \& Henderson, 2015). Scholars have argued that increasing application of corporate management policies in public institutions have made campus networks more hierarchical (Kezar, 2014; Seeber et al., 2015). Furthermore, different organisational roles can cause a hierarchical social network structure (e.g. Benz-Gydat et al., 2021). University lecturers might comprise newly hired research assistants, long-term professors, or external lecturers having few 
connections with the university organisation. Such diverse organisational roles can lead to a natural power imbalance in a social network, as reflected in a hierarchical network structure. This structure, likely visible in existing campus networks, may also characterise new networks between higher education teachers, including networks created and supported through educational reform programmes aiming to enhance teaching quality through educational innovations. Thus, we propose that:

H1: Educational innovation networks initially display a hierarchical structure.

Centralisation in educational networks negatively affects educational reform outcomes (Daly \& Finnigan, 2010). In the same vein, higher education teachers participating in an instructional development programme identified hierarchy as a critical factor that negatively impacted their interaction (Van Waes et al., 2015b). Powerful actors or groups may filter crucial information; consequently, hierarchy may inhibit innovation diffusion (de Lima, 2010; Quardokus \& Henderson, 2015).

However, Valente (2012) noted that (network) interventions can positively affect social network structure. Typically, government funds or the university's efforts support such interventions, including teaching conferences, team-based workshops, training, and networking events (Kauffeld et al., 2019a; Benz-Gydat et al., 2021; Gast et al., 2017; Hellmann et al., 2014; Jütte et al., 2017). One example of network interventions' potential positive influence on higher education teachers' networks is the opportunity for higher education teachers with different backgrounds (e.g. departments or organisational roles) to meet and establish social ties. A positive effect of (network) interventions was empirically demonstrated during an instructional development programme (Van Waes et al., 2018). However, such interventions are not usually carried out as a finite, short-term programme but are ongoing processes (Kauffeld et al., 2019a). Therefore, we postulate that:

H2: Educational innovation networks created and supported by educational reform programmes display decreasing hierarchy over time due to network interventions.

Hierarchy can also impact the global structure and unity of a network and lead to network fragmentation. Fragmentation, in turn, might block innovation diffusion and thus educational change. Researchers have pointed out that in educational networks, fragmentation or a lack of connectivity develops if individual teachers insist on their autonomy and avoid participating in collective actions and efforts (de Lima, 2010).

Higher education networks might not display enough clustering and connectivity for various reasons. For example, higher education institutions are often characterised by many conflicts (Kezar, 2014), such as limited resources for teaching and research (Schneijderberg \& Götze, 2020). Furthermore, fixed-term contracts, prevalent at universities, and a high turnover rate inhibit the organisational capability to create long-term ties between organisational members (Kauffeld et al., 2019b; Kezar, 2014; Schneijderberg \& Götze, 2020).

However, isolation is not a given in social networks. According to the "small-world" paradigm, individuals connect to some degree in most social networks and potentially might reach each other in a few steps (Milgram, 1967; Phelps et al., 2012; Watts \& Strogatz, 1998). Research has repeatedly demonstrated that network structures associated with small-worldness enhance learning and lead to social cohesion (Phelps et al., 2012; Schilling \& Phelps, 2007; Uzzi \& Spiro, 2005). In higher education, different reasons can underlie the development of small-world networks. For example, higher 
education teachers may need to design a common curriculum for a specific degree programme, requiring them to coordinate with their colleagues to ensure that the students' learning content aligns with other lectures. Innovators must also discuss their ideas with colleagues and professors, for example, to ensure compliance with module handbooks despite changes in teaching. Such tasks mandate communication and information exchange between higher education teachers in networks. Furthermore, educational reform programmes provide additional funding for teaching staff and learning (Kauffeld et al., 2019a; Benz-Gydat et al., 2021; Jütte et al., 2017), reducing conflict and enhancing communication, knowledge, and idea transfer. Accordingly, we propose that:

H3: Educational innovation networks created and supported by educational reform programmes exhibit small-world characteristics (e.g. high connectivity).

\section{Factors influencing the structure of educational innovation networks}

Scholars have identified different variables, in addition to the structure of the social network, crucial for successful (educational) innovation diffusion, including characteristics of the individuals and their environment (Cohen \& Ball, 2007; Hasanefendic et al., 2017; Wolfe, 1994). These variables are closely interconnected since individual creativity and innovation happen within the organisational context where the individual works (Amabile, 1988).

This organisational context is reflected by the organisational climate - the employees' shared perception of their work surroundings (Al-Kurdi et al., 2020; Stasewitsch et al., 2021; Patterson et al., 2005). Some scholars have referred to the individual's perception of the organisational climate as a "psychological climate" (James \& Jones, 1974; Patterson et al., 2005, p. 380), allowing organisational climate to be defined as an individual attribute of the employees. Climate can refer to different aspects of the work surroundings, and scholars have recommended "a facet-specific climate approach where climate has a focus and is tied to something of interest" to create meaningful results and contribute to organisational theory (Patterson et al., 2005, p. 381). This approach can identify the effect of specific facets of organisational climate on desired outcomes (Stasewitsch et al., 2021; Stasewitsch \& Kauffeld, 2020; Ashkanasy et al., 2000; Patterson et al., 2005).

In the context of educational innovations in higher education, the organisational climate facet of interest is the orientation toward innovation in teaching or the innovative teaching climate. This latter term describes the shared perception of higher education teachers regarding their working conditions that can positively and negatively influence change and innovation in teaching (Stasewitsch et al., 2021; Stasewitsch \& Kauffeld, 2020). Innovative teaching climate can be defined as an individual characteristic of the higher education teachers who interpret the innovative teaching climate in their university departments (Stasewitsch et al., 2021; Stasewitsch \& Kauffeld, 2020). Scholars identified innovation climate as a critical variable for developing educational innovations in higher education institutions (Benz-Gydat et al., 2021). As noted earlier, little is known about the impact of higher education teacher characteristics on education network structures (Hasanefendic et al., 2017; Kezar, 2014). Findings in this area could allow us to suggest how innovative teaching climate affects the formation of educational innovation networks. 


\section{Homophily and innovative teaching climate in educational innovation networks}

Assumptions about how individual attributes, such as innovative teaching climate, might influence network formation can be derived from the "birds of a feather" theory (also referred to as the homophily principle; McPherson et al., 2001). This theory proposes that regardless of the type of connection (e.g. friend vs colleague), social similarity or homophily is the primary process that governs social network formation. Homophily has been studied to a limited extent in academic networks (Quardokus \& Henderson, 2015). Consequently, little is known about why homophily develops in academic networks and based on which particular individual characteristics. Seeking to provide insights into this phenomenon and based on McPherson et al.'s (2001) "birds of a feather" theory, we propose that in educational innovation networks that are created and supported by an educational reform programme:

H4: Higher education teachers initially display homophilous connections regarding their perceived innovative teaching climate.

Scholars have suggested that homophily may lead to negative results in terms of educational change because of a lack of diversity in idea creation (Kezar, 2014) or teachers' isolation due to different beliefs (Qian et al., 2013). According to Daly and Finnigan (2010), internally focused or homophilous networks having little communication between school administrators and school district departments hinder change. Based on quantitative and qualitative data analysis, the authors reasoned that homophilous communication patterns inhibit an efficient transfer of different knowledge and education innovation. Homophily has also been found in educational research networks in higher education, potentially impeding interdisciplinarity, diversity, and hence innovation (Hartlep et al., 2017).

A similar result might emerge in the context of educational innovations in higher education teaching if the exchange of knowledge and ideas involves only higher education teachers with a similar perception regarding the innovative teaching climate. This case would encourage a homophilous communication pattern, potentially causing educators to miss the chance to exchange ideas with higher education teachers from departments with other backgrounds (such as different innovative teaching climates). Research has indicated that organisational climate (e.g. innovativeness) can positively influence employees' knowledge-sharing attitude, intention, and behaviour (Bock et al., 2005; Matić et al., 2017). Sharing the same perception on innovative teaching climate might be positive for knowledge transfer or innovation diffusion. However, diverse ties regarding innovative teaching climate might lead to exchanging diverse ideas and thinking. Studies have also pointed to a positive relationship between diversity and innovation (Østergaard et al., 2011).

Typical reform efforts to enhance teaching quality and promote educational innovations include material support, interventions, and events. Higher education teachers who participate in training and networking interventions and events can meet others from different departments with different innovative teaching climates. Such events allow these teachers to share different experiences and knowledge (Kauffeld et al., 2019a; Hellmann et al., 2014; Jütte et al., 2017). Hence, reform efforts increase the likelihood of collaboration between teachers from departments with different innovative teaching climates. Therefore, 
we propose that in educational innovation networks that are created and supported by an educational reform programme:

H5: Higher education teachers display a decrease in homophilous connections regarding their perceived innovative teaching climate over time due to network interventions.

\section{Method}

\section{Case description}

To gain a deeper understanding of the structure of educational innovation networks, we studied a specific network in the context of the German educational reform programme "Qualitätspakt Lehre" [Teaching Quality Pact]. This endeavour is similar to other educational reform programmes (e.g. in the United States) that fund educational innovation and networks between teachers (Peurach, 2016).

This study involved analysing an educational innovation network in the context of a medium-sized German university that had received funding to enhance its teaching and learning quality. Higher education teachers from any discipline could submit proposals within a university-internal funding programme ("Innovation Programme") describing their educational innovations. Annually or semi-annually, a jury of experts (university professors, research staff members, and student representatives) evaluated proposals and selected suitable projects. Within a fixed total amount of funding, the number of funded projects per year varied, offering the flexibility to fund numerous low-cost projects or a small number of cost-intensive projects or a mix of both types. Funding for a project typically lasted 1 year, financed one staff member (50\%), and provided additional support for educational materials and graduate assistants. In most cases, higher education teachers have proposed educational innovations designed for a specific course or discipline, aiming at the course or programme level of teaching at their university. One or only a few higher education teachers engaged in a specific educational innovation project, and often the educational innovation initially reached only a few students (Kauffeld \& Othmer, 2019; Stasewitsch et al., 2021b). Similar small-scale interventions (e.g. Towndrow et al., 2010) have gained increasing attention over the last decade. These programmes are also known as "innovative teaching projects" (Kauffeld \& Othmer, 2019; Benz-Gydat et al., 2021; Feixas et al., 2018; Hellmann et al., 2014; Jütte et al., 2017).

Funded higher education teachers were required to participate in networking events and workshops designed to provide general didactical knowledge and specific support for implementing innovative teaching projects (Kauffeld et al., 2019a). Furthermore, the university provided additional funding for a transfer programme intended to apply ideas from innovative teaching projects funded by the innovation programme to other departments ("Transfer Programme"). Usually, both the transfer providers (participants in the original innovative teaching project) and the transfer takers (who wanted to implement the project in their department) received a 50\% employee position for 1 year if their proposals were approved (Kauffeld et al., 2019a; Stasewitsch et al., 2021b). All these efforts (e.g. funding, networking events, workshops) targeted to create an educational innovation network between higher education teachers, enabling the transfer of knowledge from the educational innovations and their diffusion to other areas. 


\section{Data collection}

We identified all funded teachers and other individuals associated with the funded educational innovations (e.g. staff who participated in the proposals but did not receive funding themselves). Collecting social network data involved a survey instrument that included an initial list of 103 higher education teachers participating in the innovation and transfer programme over time. Primary data collection took place in 2016 during an annual half-day networking event. Currently funded teachers are required to attend this event. Individuals who had gained funding in a previous academic year were also invited. The participants were asked to fill out the questionnaires following the event's input presentations.

We also asked the respondents to distribute the questionnaires to others who took part in innovative teaching projects but were not included in the initial network instrument (e.g. they had supervised the project in their department) to obtain fuller, more precise information about the network. Furthermore, our network instrument's original list of participants might have been incomplete due to teachers taking sick leave or parental leave or leaving their innovative teaching projects or the university system. Teachers who could not attend the networking event did not complete the questionnaires at that time and, along with teachers who were handed the instrument later, returned their forms by mail.

Overall, 88 higher education teachers completed the network questionnaire, 82 of whom also filled in a demographic survey (Appendix, Table 1), indicating a response rate of $85.44 \%$. In all, we collected data on 1,018 social network connections for the first time point (T1) and 1,245 for the second (T2).

\section{Name generator}

We asked the respondents to name the source of teaching ideas they had adopted: "Please also indicate from whom you have taken teaching ideas from the 'Innovation or Transfer Programme' during the relevant period." We requested that they provide data on this exchange for the current academic year (Autumn 2015-Autumn 2016=T2) and, retrospectively, the previous year (Autumn 2014-Autumn 2015=T1; for retrospective data collection, see Mikolajczyk \& Kretzschmar, 2008). The number of network nominations was unlimited.

\section{Social network methods}

For this study, we used SNA to investigate our research questions exploring an educational innovation network's efficiency. Evaluating networks requires having a concept of the "good, the effective, the productive network" (Rogers et al., 2001, p. 171) and understanding different criteria by which a network can be judged as satisfactory. We used two approaches to determine network efficiency. First, we evaluated efficiency by identifying beneficial network structures (e.g. small-worldness) and analysing whether these network characteristics became more pronounced over time (Stoll et al., 2006).

Second, we compared the identified network characteristics or structures with random graphs based on empirical networks (Erdös \& Rényi, 1959; Newman, 2001; Opsahl, 2013; Watts \& Strogatz, 1998) via a tie-reshuffling procedure and a permutation test (see Appendix, Table 2 for details; Christakis \& Fowler, 2013). This approach allowed examining whether the network characteristics (e.g. centrality or path length) were more pronounced than might be expected by chance. In the frames of these randomisation approaches, we 
compared the existing network parameters with the distribution drawn from 100,000 random same-sized networks (Fredrickson \& Chen, 2019).

\section{Social network variables}

Hierarchy The centralisation index calculated the heterogeneity of the degree centralities (number of the individual's contacts), ranging from 0 to 1 (Wasserman \& Faust, 1994). Centralisation was 1 for the star network since one central actor directly contacts every other network member, while the rest of the network members were not connected. Centralisation equalled 0 when all actors had the same centrality index.

Small-worldness Small-worldness reflects connectivity in the network. Thus, we considered a set of network parameters to describe the network structure. First, we examined the clustering coefficient (CC), ranging from 0 to 1 , to identify whether dense groups emerged within the educational innovation network. The $\mathrm{CC}$ equalled 0 if no triangles existed in the network and 1 if all 2-paths were closed (Opsahl, 2013). In other words, $\mathrm{CC}=$ number of all closed 2-paths (triplets) in the network / total number of 2-paths. Next, we looked at the network's path length to analyse whether a group of higher education teachers in the educational innovation network displayed connections that facilitated rapid information transfer. This measure indicated the average number of steps along the shortest paths for all possible pairs of members in the network (Ansell et al., 2017). Lastly, we calculated the small-world coefficient to analyse whether the educational network exhibited a short path length and high clustering (Ansell et al., 2017). This index was determined by dividing the global $\mathrm{CC}$ by the average path length from an empirical network and dividing this quotient by the similar ratio of a random graph based on the same number of nodes as the empirical network. In a recent study, Opsahl et al. (2017) criticised the use of the smallworld coefficient, arguing that networks are too easily identified as small worlds. Thus, we followed the authors' methodology, a mathematical approach that uses simulations to avoid this problem. Specifically, we evaluated small worldness in the educational innovation network by comparing it with a high number of random networks based on Opsahl et al.'s tie reshuffling algorithm.

Homophily The E-I index showed the extent to which intra- and intergroup processes characterised communication in a network (Krackhardt \& Stern, 1988). This index could be used to evaluate the degree of homophily in the educational innovation network and represented the relationship between the external and internal number of ties based on a specific actor attribute (in this case, innovative teaching climate): E-I index $=($ external ties - internal ties) / (external ties + internal ties). The E-I index ranged from - 1 (where all the connections were between individuals with the same characteristics, meaning complete homophily) to 1 (where all the ties were between individuals with different characteristics, meaning zero homophily; see Daly \& Finnigan, 2010; Krackhardt \& Stern, 1988).

Innovative teaching climate Our investigation involved the use of a self-developed scale for innovative teaching climate, $a_{\mathrm{T} 1}=0.68, a_{\mathrm{T} 2}=0.72$, that focused on the attitude of higher education teachers toward change in teaching, for example, "Our teachers are willing to take risks to improve their teaching" (see Kauffeld et al., 2004; Stasewitsch \& Kauffeld, 2020; see also Appendix, Table 3). 


\section{Results}

The appendix (Table 1) presents the descriptive results for both educational innovation networks. The average degree (the number of individuals nominated by an actor) increased from $\mathrm{T}_{1}, \mathrm{~d}_{\mathrm{T} 1}=1.79$, to $\mathrm{T}_{2}, \mathrm{~d}_{\mathrm{T} 2}=2.15$, indicating that the participating higher education teachers built more connections in the educational innovation network over time.

We postulated that the educational innovation network would initially display a hierarchical structure (H1) and that this tendency would decrease over time (H2). Our results showed that centralisation in the educational innovation network at $\mathrm{T} 1, \mathrm{C}_{\mathrm{T} 1}=0.12$, was statistically significantly higher than in same-sized random networks, $\mathrm{C}_{\mathrm{T} 1 \mathrm{random}}=0.04,95 \%$ $\mathrm{CI}=[0.04,0.05], p<0.0001$. This outcome can be interpreted as support for H1, indicating that the number of connections within a social network was initially distributed more heterogeneously than could be expected by chance. In other words, we found the presence of hierarchical structures in the network. Furthermore, hierarchy decreased over time, $\mathrm{C}_{\mathrm{T} 2}=0.10$, providing support for $\mathrm{H} 2$.

We also hypothesised that the educational innovation network would exhibit smallworld patterns (H3). The small-world quotient was larger than 1 for both time points, $\mathrm{Q}_{\mathrm{T} 1}=2.32$ and $\mathrm{Q}_{\mathrm{T} 2}=2.53$. Furthermore, our findings revealed that the average path length was statistically significantly shorter in the empirical educational innovation network, $1_{\mathrm{T} 1}=3.61$ and $1_{\mathrm{T} 2}=3.64$, than in the random networks, $1_{\mathrm{T} 1 \text { random }}=3.65,95 \%, \mathrm{CI}=[3.64$, $3.65]$ and $1_{\mathrm{T} 2 \text { random }}=3.71,95 \% \mathrm{CI}=[3.70,3.71]$; moreover, $p<0.001$ for both $\mathrm{T} 1$ and $\mathrm{T} 2$. The $\mathrm{CC}$ was statistically significantly higher in the empirical educational innovation network, $\mathrm{CC}_{\mathrm{T} 1}=0.19$ and $\mathrm{CC}_{\mathrm{T} 2}=0.22$, than in the random networks, $\mathrm{CC}_{\mathrm{T} 1 \text { random }}=0.082,95 \%$ $\mathrm{CI}=[0.081,0.082]$ and $\mathrm{CC}_{\mathrm{T} 2 \text { random }}=0.089,95 \% \mathrm{CI}=[0.088,0.089]$, and $p<0.001$ for both $\mathrm{T} 1$ and $\mathrm{T} 2$ ). These results reflect that the teachers increased their connectivity within the educational innovation network over time. Overall, these findings together empirically support $\mathrm{H} 3$ and indicate that the studied educational innovation network was a small world.

Our investigations focused on the role of innovative teaching climate as an individual characteristic in network formation in an educational innovation network. In this context, we postulated that higher education teachers would initially display homophilous connections in terms of their innovative teaching climate (H4). The E-I index for innovative teaching climate in the educational innovation network was statistically significantly lower, $\mathrm{EI}_{\mathrm{T} 1}=-0.14$, than in random networks at $\mathrm{T}_{1}, \mathrm{EI}_{\mathrm{T} 1 \text { random }}=0.002,95 \% \mathrm{CI}=[0.0022$, $0.0024], p<0.001$. This outcome indicates that the higher education teachers initially tended to create connections with those who had similar levels of innovative teaching climate levels, supporting H4.

Furthermore, we postulated that higher education teachers would display a decrease in homophilous connections related to their perceived innovative teaching climate over time due to network interventions (H5). Our findings demonstrated that the level of homophily decreased by almost half over time, from $\mathrm{EI}_{\mathrm{T} 1}=-0.14$ to $\mathrm{EI}_{\mathrm{T} 2}=-0.07$ (Fig. 1). Our results suggest support for $\mathrm{H} 5$.

\section{Discussion}

Scholars have previously identified the "need to artificially construct or support networking to facilitate change" in higher education (Kezar, 2014, p. 111). This argument aligns with discussions of professional networks' role in teaching (e.g. Van Waes et al., 2018) and 


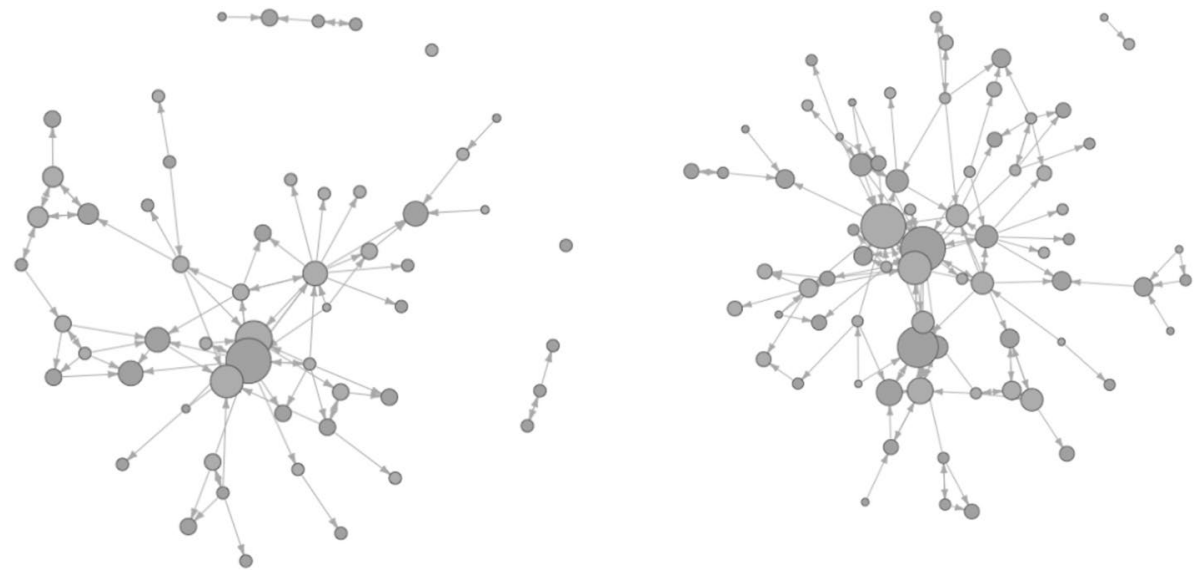

Fig. 1 Educational innovation network for T1 (left) and T2 (right). Orange nodes = high innovative teaching climate. Blue nodes = low level of innovative teaching climate. Node size reflects teachers' indegree centrality

supporting educational innovations (e.g. Benz-Gydat et al., 2021; Feixas et al., 2018; Jütte et al., 2017). Because networks in education do not occur naturally, reforms and change programmes have been implementing strategies to create professional connections between teachers to achieve positive changes (Kauffeld et al., 2019a; Benz-Gydat et al., 2021; de Lima, 2010; Jütte et al., 2017; Portes, 1998).

However, little is known about teachers' networks in higher education and the diffusion of educational innovations within these structures (Kezar, 2014). Following the evaluation framework of Cohen and Ball (2007) and its application by Towndrow et al. (2010), we sought to close this research gap by focusing on innovation diffusion processes in educational innovation networks. Furthermore, we wanted to investigate factors that might affect the networks' structure.

In line with our first hypothesis, we found that the network's hierarchy decreased over time. Initially, we found that hierarchy was present to some degree in the network. One reason for this finding might include preferential attachment (also called the Matthew effect) in the network, meaning the tendency for popular actors or individuals in a network to gain more popularity and activity, which other studies analysing higher education (research) networks have also reported (Vlegels \& Huisman, 2021). This effect might arise if a network expands. New network members' preference to connect to already popular (and powerful) individuals in the network means the latter gain additional contacts (Vlegels \& Huisman, 2021). Also, the initial hierarchy in the educational innovation network conceivably reflects the organisational hierarchy in the university. Higher education teachers or groups of higher education teachers might initially benefit from their high status in the university (e.g. due to their reputation(s), organisational role(s), or access to resources), leading to a favourable position in the network.

Nevertheless, networking interventions can decrease hierarchy over time (e.g., Stasewitsch et al., 2021b). In concrete terms, this decrease might indicate the redistribution of the network hierarchy where higher education teachers or groups of teachers who might initially have a better network position in the educational innovation network "lose" these 
beneficial structural positions over time, while individuals or groups from the periphery of the network might increase their number of connections.

We consider this effect a positive development in a network, potentially facilitating innovation and knowledge transfer. Less hierarchy leads to a dispersal of power, which is vital for innovation development and diffusion (Damanpour, 1991). Moreover, a decrease in hierarchy might reduce communication costs and allow faster and more effective exchanges between higher education teachers in different positions (e.g. members of either the network core or the periphery) who might also differ in their background (e.g. department, organisational position, professional experience). In turn, these new, diverse connections might lead to the generation of (teaching-related) ideas (e.g. Østergaard et al., 2011).

We found support for the assumption that educational reform efforts promote smallworld structures in teachers' innovation networks, observing the formation of dense groups between higher education teachers, which promoted knowledge sharing (Schilling \& Phelps, 2007; Uzzi \& Spiro, 2005) regarding educational innovations. Our results demonstrated that higher education teachers could reach each other through four steps, on average, illustrating that rapid idea exchange was possible. These findings agree with various studies demonstrating small-world networks beneficial for an organisation's innovation and productivity (e.g. Verspagen \& Duysters, 2004).

In summary, these results indicate that the strategies (e.g. networking events for higher education teachers, workshops, training, symposia; Kauffeld et al., 2019a; Benz-Gydat et al., 2021; Hellmann et al., 2014; Jütte et al., 2017) that educational reform programmes introduce lead to efficient network structures. This finding supports prior research reporting the positive effect of training or professional development programmes on social network development (Van den Bossche \& Segers, 2013; Van Waes et al., 2018). Furthermore, our results align with current research on knowledge transfer in higher education institutions. Using a questionnaire design, Fauzi et al. (2019) demonstrated that social networks positively influenced knowledge sharing attitudes, which positively influenced the knowledge sharing intention of academics in turn. We have expanded the current research through quantitative structural SNA, demonstrating that social networks in higher education (especially educational innovation networks) can be created and supported through networking interventions that support knowledge transfer and innovation diffusion.

We also examined the factors contributing to network formation, evaluating how the perceived innovative teaching climate influenced idea exchange in an educational innovation network. In line with the homophily principle (McPherson et al., 2001), we found a moderate tendency toward homophily in the network. While this outcome suggests highquality network connections that enhance knowledge transfer involving complex issues, the pattern could also represent a disadvantage, as the exchange of diverse strategies and knowledge (of the best way to develop and implement educational innovations) might have been insufficient (e.g. Van Waes et al., 2015a). Higher education teachers whose departments' innovative teaching climate is relatively low, may significantly benefit from partners whose departments (and possibly professors) are enthusiastic about educational innovations, resulting in spillover effects. Over time, the data indicated a positive trend in the educational innovation network and decreased homophily, suggesting tie formation between teachers experiencing different levels of innovative teaching climate. Hence, higher education teachers with different backgrounds exchange ideas in the educational innovation network over time. Thus, innovations might have been shared or communicated to departments where teaching and innovation in teaching may have had a lower priority. We argue that this finding indicates that innovations - if shared in educational innovation networks 
supported by network interventions - can influence attitudes and pedagogical practices (see Benz-Gydat et al., 2021; Civis et al., 2019; Fullan, 2010; Jütte et al., 2017).

This study has several strengths. Our empirical results arguably tackle issues that educational research has not sufficiently addressed to date (e.g. Kezar, 2014), such as the influence of individual teacher-related attributes on network formation (Hasanefendic et al., 2017) or the power distribution (hierarchy) in educational networks (de Lima, 2010). We also drew upon two essential features of Cohen and Ball's (2007) evaluation framework of educational innovations - innovation diffusion processes and the environment's role - and applied these to the context of higher education innovation.

Using diffusion processes to evaluate the success of educational innovations sets a high standard (Towndrow et al., 2010); nevertheless, we found indications that innovation diffusion can be achieved through network interventions. This study is one of the first to provide empirical insights about the structure of educational innovation networks (e.g. their hierarchy) using actual structural social network methods. We have demonstrated that higher education teachers diffuse their ideas efficiently through working in dense groups while at the same time maintaining short connections with each other. Moreover, we did not merely map a "funding network" but asked higher education teachers to indicate from whom they took innovative ideas (regarding other educational innovations). Hence, we analysed and revealed (e.g. through our results on small-worldness and hierarchy) the existence of real idea exchange between higher education teachers in the educational innovation network beyond funding.

\section{Practical implications}

For those responsible for educational reform programmes (in the government, ministries, and at the university level), our results support the conclusion that deploying financial and human resources to create educational innovation networks is worthwhile, allowing efficient diffusion of educational innovations. Our findings also indicate the need for (further) network interventions. As an innovative teaching climate plays a crucial role in the educational innovation network structure, university practitioners should emphasise diverse collaborations between higher education teachers (e.g. between different departments with different innovative teaching climates).

\section{Limitations and further research}

We analysed an educational innovation network that was promoted through funding, yielding detailed insights into the network structure. However, further research is needed to determine generalisability in other contexts. Our findings regarding the hierarchy of the educational innovation network, including its decreasing over time, are in line with recent studies indicating that innovation networks in higher education do not display a tendency for hierarchy (Stasewitsch et al., 2021b). However, to some degree, this result contradicts other research on preferential attachment in higher education (e.g. Vlegels \& Huisman, 2021). Hence, we propose that more research is needed to scrutinise the structure of different networks in higher education and to understand what drives the formation of academic networks (e.g. Stasewitsch et al., 2021). Furthermore, our results on homophily contradict other studies in higher education that did not find homophily (e.g. based on gender or job title) in academic networks (Quardokus $\&$ Henderson, 2015). Thus, further studies should identify mechanisms that enhance or inhibit 
homophily in educational networks. Another limitation is the absence of data on the organisational hierarchy. Universities' inherent formal hierarchical structure might affect the diffusion of information, innovation, and resources within the university as well as in educational innovation networks. We suppose this is a critical issue for further study (e.g. by analysing multiplex network structures). In addition, further research should focus on different (network) interventions and how those influence educational innovation and change in higher education teaching (Stasewitsch \& Kauffeld, 2021).

\section{Conclusion}

Circumstances in higher education teaching are typically uncertain due to various factors such as globalisation or new technologies (Kozma, 1985; Taylor, 1998). Innovation appears to be a pivotal aspect to adapting and creating change. However, research on mechanisms that lead to change through educational innovation remains scarce; moreover, few studies have employed SNA to uncover the structure of educational networks (Kezar, 2014). We found that network interventions (e.g. networking events, training, or teaching conferences; Kauffeld et al., 2019a; Jütte et al., 2017; Van Waes et al., 2018) could establish structures in an educational innovation network that promoted innovation diffusion (e.g. a short path length). This outcome indicates that networks accompanying educational innovations can create change in higher education teaching.

\section{Appendix}

Tables 1, 2 and 3

Table.1 Descriptive Statistics for the Educational Innovation Network and Attributes of Network Members

\begin{tabular}{lll}
\hline Parameter & T1 & T2 \\
\hline Nodes & 100 & 115 \\
Edges & 179 & 251 \\
Density & 0.02 & 0.02 \\
Average degree & 1.79 & 2.18 \\
Sex (female, male, no response) & - & $27 \%, 36 \%, 37 \%$ \\
Mean age $(S D)$ & - & $39.93(10.96)$ \\
Mean no. teaching semesters $(S D)$ & - & $17.76(15.27)$ \\
Role in the university: professors, postdoc- & - & $22 \%, 5.0 \%, 18 \%$ \\
$\quad$ toral candidates, predoctoral candidates & & \\
\hline
\end{tabular}

Note. Details on sex, age, no. teaching semesters, and role are only mentioned for $\mathrm{T} 2$ due to the retrospective data collection method in this study. 
Table.2 Tie-Reshuffling

Procedure and Permutation Test

\begin{tabular}{ll}
\hline Statistical procedure & Description \\
\hline Tie-reshuffling procedure & $\begin{array}{c}\text { The tie-reshuffling procedure cre- } \\
\text { ates a random network by rewir- } \\
\text { ing the existing ties between the } \\
\text { actors, maintaining the degree } \\
\text { centrality of each actor (Opsahl } \\
\text { et al., 2017). This technique } \\
\text { makes creating a random network } \\
\text { possible, identical to the initial } \\
\text { degree of distribution and with } \\
\text { a completely distinct topological } \\
\text { structure. } \\
\text { The permutation test is applied } \\
\text { to reveal specific features of the } \\
\text { observed network (Christakis \& } \\
\text { Fowler, 2013) and maintains the } \\
\text { original network structure in cre- } \\
\text { ating a random network. Further- } \\
\text { more, individual characteristics } \\
\text { (e.g. innovative teaching climate) } \\
\text { can be randomly assigned. }\end{array}$ \\
\end{tabular}

Table.3 Items on Innovative Teaching Climate

\begin{tabular}{lc}
\hline Items in German & English translation \\
\hline $\begin{array}{l}\text { Die Lehrenden bei uns sind bereit Risiken einzugehen, um die Lehre zu } \\
\text { verbessern. }\end{array}$ & $\begin{array}{c}\text { Our teachers are willing } \\
\text { to take risks in order to } \\
\text { improve their teaching. }\end{array}$ \\
$\begin{array}{l}\text { Die Lehrenden bei uns nehmen an vielen hochschuldidaktischen Weiter- } \\
\text { bildungen innerhalb unserer Universität teil. }\end{array}$ & $\begin{array}{c}\text { Our teachers participate in } \\
\text { many didactical training } \\
\text { courses at our university. }\end{array}$ \\
$\begin{array}{l}\text { Die Lehrenden bei uns nehmen an vielen hochschuldidaktischen Weiter- } \\
\text { bildungen außerhalb unserer Universität teil. }\end{array}$ & $\begin{array}{c}\text { Our teachers take part in many } \\
\text { didactical training courses }\end{array}$ \\
$\begin{array}{l}\text { Veränderungen in der Lehre werden durch die Lehrenden bei uns unter- } \\
\text { stützt. }\end{array}$ & $\begin{array}{c}\text { Changes in teaching are sup- } \\
\text { ported by our teachers. }\end{array}$ \\
$\begin{array}{c}\text { Die Lehrenden bei uns tauschen sich regelmäßig mit Experten außerhalb } \\
\text { unserer Universität zu hochschuldidaktischen Themen aus (z.B. zur }\end{array}$ & $\begin{array}{c}\text { Our teachers regularly exchange } \\
\text { ideas with experts outside our } \\
\text { Curriculumsentwicklung). }\end{array}$ \\
$\begin{array}{l}\text { university on topics related } \\
\text { to didactic studies (e.g. cur- } \\
\text { riculum development). }\end{array}$
\end{tabular}

Note. Items for innovative teaching climate were answered on a scale from 1 (do not agree) to 5 (highly agree). 
Funding Open Access funding enabled and organized by Projekt DEAL. This work was supported by the German Ministry of Education and Research under grant 01PL17043. Sofia Dokuka gratefully acknowledges support from the Basic Research Program of the National Research University Higher School of Economics (Moscow).

\section{Declarations}

Ethics approval The study was approved by the ethics committee of the faculty 2, TU Braunschweig: DM-2016-03.

Consent to participate Informed consent was obtained from the participants of the study.

Disclosure statement The authors have no conflict of interest to disclose.

Open Access This article is licensed under a Creative Commons Attribution 4.0 International License, which permits use, sharing, adaptation, distribution and reproduction in any medium or format, as long as you give appropriate credit to the original author(s) and the source, provide a link to the Creative Commons licence, and indicate if changes were made. The images or other third party material in this article are included in the article's Creative Commons licence, unless indicated otherwise in a credit line to the material. If material is not included in the article's Creative Commons licence and your intended use is not permitted by statutory regulation or exceeds the permitted use, you will need to obtain permission directly from the copyright holder. To view a copy of this licence, visit http://creativecommons.org/licenses/by/4.0/.

\section{References}

Al-Kurdi, O., El-Haddadeh, R., \& Eldabi, T. (2018). Knowledge transfer in higher education institutions: A systematic review. Journal of Enterprise Information Management, 31(2), 226-246. https://doi.org/10. 1108/JEIM-09-2017-0129

Al-Kurdi, O. F., El-Haddadeh, R., \& Eldabi, T. (2020). The role of organisational climate in managing knowledge sharing among academics in higher education. International Journal of Information Management, 50, 217-227. https://doi.org/10.1016/j.ijinfomgt.2019.05.018

Amabile, T. M. (1988). A model of creativity and innovation in organizations. Research in Organizational Behavior, 10(1), 123-167.

Ansell, C., Lundin, M., \& Öberg, P. O. (2017). Learning networks among Swedish municipalities: Is Sweden a small-world? In J. Glückler, E. Lazega, \& I. Hammer (Eds.), Knowledge and networks (pp. 315336). Springer.

Ashkanasy, N. M., Wilderom, C. P. M., \& Peterson, M. F. (2000). Handbook of organizational culture and climate. Sage.

Benz-Gydat, M., Jütte, W., Lobe, C., Walber, M. (2021). Neue Lehre in der Hochschule. Verstetigung innovativer Lehrprojekte in sozialen Hochschulwelten. [New teaching in higher education. Sustainability of innovative teaching projects in social university environments]. WBV. https://doi.org/10.3278/60049 $02 \mathrm{~W}$

Bock, G. W., Zmud, R. W., Kim, Y. G., \& Lee, J. N. (2005). Behavioral intention formation in knowledge sharing: Examining the roles of extrinsic motivators, social-psychological forces, and organizational climate. MIS Quarterly, 29(1), 87-111.

Bruckmann, S., \& Carvalho, T. (2018). Understanding change in higher education: An archetypal approach. Higher Education, 76(4), 629-647. https://doi.org/10.1007/s10734-018-0229-2

Christakis, N. A., \& Fowler, J. H. (2013). Social contagion theory: Examining dynamic social networks and human behavior. Statistics in Medicine, 32(4), 556-577. https://doi.org/10.1002/sim.5408

Civis, M., Diaz-Gibson, J., López, S., \& Moolenaar, N. (2019). Collaborative and innovative climates in preservice educator programs: The role of social capital. International Journal of Educational Research, 98, 224-236. https://doi.org/10.1016/j.ijer.2019.08.019

Clark, T. N. (1968). Institutionalization of innovations in higher education: Four models. Administrative Science Quarterly, 13(1), 1-25. 
Cohen, D. K., \& Ball, D. L. (2007). Educational innovation and the problem of scale. In B. Schneider \& S. K. McDonald (Eds.), Scale up in education: Ideas in principle (pp. 19-36). Rowman \& Littlefield Publishers.

Daly, A. J., \& Finnigan, K. S. (2010). A bridge between worlds: Understanding network structure to understand change strategy. Journal of Educational Change, 11(2), 111-138. https://doi.org/10.1007/ s10833-009-9102-5

Damanpour, F. (1991). Organizational innovation: A meta-analysis of effects of determinants and moderators. Academy of Management Journal, 34(3), 555-590. https://doi.org/10.5465/256406

De Lima, J. Á. (2010). Thinking more deeply about networks in education. Journal of Educational Change, 11(1), 1-21. https://doi.org/10.1007/s10833-008-9099-1

Erdös, P., \& Rényi, A. (1959). On random graphs. Publicationes Mathematicae, 6, 290-297. https://doi. org/10.1515/9781400841356.38

Fauzi, M. A., Tan, C. N. L., Thurasamy, R., \& Ojo, A. O. (2019). Evaluating academics' knowledge sharing intentions in Malaysian public universities. Malaysian Journal of Library \& Information Science, 24(1), 123-143. https://doi.org/10.22452/mjlis.vol24no1.7

Feixas, M., Martínez-Usarralde, M. J., \& López-Martín, R. (2018). Do teaching innovation projects make a difference? Assessing the impact of small-scale funding. Tertiary Education and Management, 24(4), 267-283. https://doi.org/10.1080/13583883.2017.1417470

Fredrickson, M. M., \& Chen, Y. (2019). Permutation and randomization tests for network analysis. Social Networks, 59, 171-183. https://doi.org/10.1016/j.socnet.2019.08.001

Fullan, M. (2010). All systems go: The change imperative for whole system reform. Corwin Press.

Gast, I., Schildkamp, K., \& Van der Veen, J. T. (2017). Team-based professional development interventions in higher education: A systematic review. Review of Educational Research, 87(4), 736-767. https://doi. org/10.3102/0034654317704306

Hartlep, N. D., Hensley, B. O., Wells, K. E., Brewer, T. J., Ball, D., \& McLaren, P. (2017). Homophily in higher education: Historicizing the AERA member-to-fellow pipeline using theories of social reproduction and social networks. Policy Futures in Education, 15(6), 670-694. https://doi.org/10.1177/ 1478210317715815

Hannan, A., English, S., \& Silver, H. (1999). Why innovate? Some preliminary findings from a research project on innovations in teaching and learning in higher education. Studies in Higher Education, 24(3), 279-289. https://doi.org/10.1080/03075079912331379895

Hasanefendic, S., Birkholz, J. M., Horta, H., \& Van der Sijde, P. (2017). Individuals in action: Bringing about innovation in higher education. European Journal of Higher Education, 7(2), 101-119. https:// doi.org/10.1080/21568235.2017.1296367

Hellmann, J. H., Paus, E., \& Jucks, R. (2014). How can innovative teaching be taught? Insights from higher education. Psychology Learning \& Teaching, 13(1), 43-51. https://doi.org/10.2304/plat.2014.13.1.43

James, L. R., \& Jones, A. P. (1974). Organizational climate: A review of theory and research. Psychological Bulletin, 81, 1096-1112.

Jütte, W., Walber, M., \& Lobe, C. (2017). Das Neue in der Hochschullehre [The new in teaching]. Springer. https://doi.org/10.1007/978-3-658-13777-9_5

Kauffeld, S., \& Othmer, J. (2019). Handbuch innovative Lehre [Handbook innovative teaching]. Springer. https://doi.org/10.1007/978-3-658-22797-5

Kauffeld, S., Jonas, E., Grote, S., Frey, D., \& Frieling, E. (2004). Innovationsklima-Konstruktion und erste psychometrische Überprüfung eines Messinstrumentes [innovation climate construction and first psychometric test of a measurement instrument]. Diagnostica, 50(3), 153-164. https://doi.org/10.1026/ 0012-1924.50.3.153

Kauffeld, S., Stasewitsch, E., de Wall, K., \& Othmer, J. (2019a). Innovationen in der Hochschullehre das Beispiel Technische Universität Braunschweig [Innovations in University Teaching - the Example of the Technical University of Braunschweig]. In S. Kauffeld \& J. Othmer (Eds.), Handbuch innovative Lehre [Handbook innovative teaching] (pp. 1-42). Springer. https://doi.org/10.1007/ 978-3-658-22797-5_1

Kauffeld, S., Spurk, D., Barthauer, L., \& Kaucher, P. (2019b). Auf dem Weg zur Professur? Laufbahnen im wissenschaftlichen Kontext. In S. Kauffeld \& D. Spurk (Hrsg.), Handbuch Karriere und Laufbahnmanagement (S. 291-325). Springer. https://doi.org/10.1007/978-3-662-48750-1_10

Kezar, A. (2014). Higher education change and social networks: A review of research. The Journal of Higher Education, 85(1), 91-125. https://doi.org/10.1080/00221546.2014.11777320

Kozma, R. B. (1985). A grounded theory of instructional innovation in higher education. The Journal of Higher Education, 56(3), 300-319. https://doi.org/10.1080/00221546.1985.11780692

Krackhardt, D., \& Stern, R. N. (1988). Informal networks and organizational crises: An experimental simulation. Social Psychology Quarterly, 51(2), 123-140. https://doi.org/10.2307/2786835 
Martins, E. C., \& Terblanche, F. (2003). Building organisational culture that stimulates creativity and innovation. European Journal of Innovation Management, 6(1), 64-74. https://doi.org/10.1108/14601 060310456337

Matić, D., Cabrilo, S., Grubić-Nešić, L., \& Milić, B. (2017). Investigating the impact of organizational climate, motivational drivers, and empowering leadership on knowledge sharing. Knowledge Management Research \& Practice, 15(3), 431-446. https://doi.org/10.1057/s41275-017-0063-9

McPherson, M., Smith Lovin, L., \& Cook, J. M. (2001). Birds of a feather: Homophily in social networks. Annual Review of Sociology, 27(1), 415-444. https://doi.org/10.1146/annurev.soc.27.1.415

Mikolajczyk, R. T., \& Kretzschmar, M. (2008). Collecting social contact data in the context of disease transmission: Prospective and retrospective study designs. Social Networks, 30(2), 127-135. https://doi.org/ 10.1016/j.socnet.2007.09.002

Milgram, S. (1967). The Small-World Problem. Psychology Today, 2(1), 60-67.

Newman, M. E. (2001). Scientific collaboration networks. Network construction and fundamental results. Physical Review E, 64(1), 1-8. https://doi.org/10.1103/PhysRevE.64.016131

Opsahl, T. (2013). Triadic closure in two mode networks: Redefining the global and local clustering coefficients. Social Networks, 35(2), 159-167. https://doi.org/10.1016/j.socnet.2011.07.001

Opsahl, T., Vernet, A., Alnuaimi, T., \& George, G. (2017). Revisiting the small-world phenomenon: Efficiency variation and classification of small-world networks. Organizational Research Methods, 20(1), 149-173. https://doi.org/10.1177/1094428116675032

Østergaard, C. R., Timmermans, B., \& Kristinsson, K. (2011). Does a different view create something new? The effect of employee diversity on innovation. Research Policy, 40(3), 500-509.

Patterson, M. G., West, M. A., Shackleton, V. J., Dawson, J. F., Lawthom, R., Maitlis, S., et al. (2005). Validating the organizational climate measure: Links to managerial practices, productivity and innovation. Journal of Organizational Behavior, 26(4), 379-408. https://doi.org/10.1002/job.312

Peurach, D. J. (2016). Innovating at the nexus of impact and improvement: Leading educational improvement networks. Educational Researcher, 45(7), 421-429. https://doi.org/10.3102/0013189X16670898

Phelps, C., Heidl, R., \& Wadhwa, A. (2012). Knowledge, networks, and knowledge networks: A review and research agenda. Journal of Management, 38(4), 1115-1166. https://doi.org/10.1177/0149206311 432640

Portes, A. (1998). Social capital: Its origins and applications in modern sociology. Annual Review of Sociology, 24(1), 1-24. https://doi.org/10.1146/annurev.soc.24.1.1

Prell, C. (2012). Social network analysis: History, theory and methodology. Sage.

Qian, H., Youngs, P., \& Frank, K. (2013). Collective responsibility for learning: Effects on interactions between novice teachers and colleagues. Journal of Educational Change, 14(4), 445-464. https://doi. org/10.1007/s10833-013-9210-0

Quardokus, K., \& Henderson, C. (2015). Promoting instructional change: Using social network analysis to understand the informal structure of academic departments. Higher Education, 70(3), 315-335. https:// doi.org/10.1007/s10734-014-9831-0

Rogers, E. M. (1995). Diffusion of innovations (4th ed.). ACM The Free Press.

Rogers, J. D., Bozeman, B., \& Chompalov, I. (2001). Obstacles and opportunities in the application of network analysis to the evaluation of R\&D. Research Evaluation, 10(3), 161-172. https://doi.org/10.3152/ 147154401781777033

Schilling, M. A., \& Phelps, C. C. (2007). Interfirm collaboration networks: The impact of large scale network structure on firm innovation. Management Science, 53(7), 1113-1126. https://doi.org/10.1287/ mnsc. 1060.0624

Schneijderberg, C., \& Götze, N. (2020). Organisierte, metrifizierte und exzellente Wissenschaftler* innen. Veränderungen der Arbeits- und Beschäftigungsbedingungen an Fachhochschulen und Universitäten von 1992 über 2007 bis 2018. [Organized, metricated, and excellent scientists. Changes in Working and Employment Conditions at Applied Higher Education Institutions and Universities from 1992 to 2007 and 2018]. INCHER Working Paper 13. Kassel INCHER. https://www.uni-kassel.de/einrichtun gen/fileadmin/datas/einrichtungen/incher/Aktuelles/Buecher_bilder/INCHERWorkingPaper13.pdf. Accessed 19 Dec 2021

Seeber, M., Lepori, B., Montauti, M., Enders, J., De Boer, H., Weyer, et al. (2015). European universities as complete organizations? Understanding identity, hierarchy and rationality in public organizations. Public Management Review, 17(10), 1444-1474. https://doi.org/10.1080/14719037.2014.943268

Stasewitsch, E., \& Kauffeld, S. (2020). Der Inno-Lehre. Ein Inventar zur Messung von innovativem LehrLernklima an Hochschulen [The Inno-Teaching. An inventory to measure innovative teaching-learning climate in higher education institutions.]. Diagnostica, 66(4), 258-268. https://doi.org/10.1026/0012$1924 / \mathrm{a} 000256$ 
Stasewitsch, E., \& Kauffeld, S. (2021). Akademische Fachzirkel: Können gruppenbasierte Interventionen zu nachhaltigen Veränderungsprozessen in Hochschulen beitragen? [Academic Circles: Can group-based interventions contribute to contribute to sustainable change processes in universities?]. Das Hochschulwesen, 69(4), 103-110.

Stasewitsch, E., Dokuka, S., \& Kauffeld, S. (2021a). What drives network evolution in communities of practice in higher education teaching? Understanding the roles of reciprocity, transitivity, and social selection. [Manuscript submitted for publication]. Lehrstuhl für Arbeits-, Organisations- und Sozialpsychologie, TU Braunschweig.

Stasewitsch, E., Barthauer, L. \& Kauffeld, S. (2021b). Knowledge transfer in a two-mode network between higher education teachers and their innovative teaching projects. Journal of Learning Analytics (in press).

Stoll, L., Bolam, R., McMahon, A., Wallace, M., \& Thomas, S. (2006). Professional learning communities: A review of the literature. Journal of Educational Change, 7(4), 221-258. https://doi.org/10.1007/ s10833-006-0001-8

Taylor, P. G. (1998). Institutional change in uncertain times: Lone ranging is not enough. Studies in Higher Education, 23(3), 269-279. https://doi.org/10.1080/03075079812331380246

Towndrow, P. A., Silver, R. E., \& Albright, J. (2010). Setting expectations for educational innovations. Journal of Educational Change, 11(4), 425-455. https://doi.org/10.1007/s10833-009-9119-9

Uzzi, B., \& Spiro, J. (2005). Collaboration and creativity: The small-world problem. American Journal of Sociology, 111(2), 447-504. https://doi.org/10.1086/432782

Valente, T. W. (2012). Network interventions. Science, 337(6090), 49-53. https://doi.org/10.1126/science. 1217330

Van den Bossche, P., \& Segers, M. (2013). Transfer of training: Adding insight through social network analysis. Educational Research Review, 8, 37-47. https://doi.org/10.1016/j.edurev.2012.08.002

Van Waes, S., De Maeyer, S., Moolenaar, N. M., Van Petegem, P., \& Van den Bossche, P. (2018). Strengthening networks: A social network intervention among educators. Learning and Instruction, 53, 34-49. https://doi.org/10.1016/j.learninstruc.2017.07.005

Van Waes, S., Van den Bossche, P., Moolenaar, N. M., De Maeyer, S., \& Van Petegem, P. (2015a). Know who? Linking faculty's networks to stages of instructional development. Higher Education, 70(5), 807-826. https://doi.org/10.1007/s10734-015-9868-8

Van Waes, S., Van den Bossche, P., Moolenaar, N. M., Stes, A., \& Van Petegem, P. (2015b). Uncovering changes in university teachers' professional networks during an instructional development program. Studies in Educational Evaluation, 46, 11-28.

Verspagen, B., \& Duysters, G. (2004). The small-worlds of strategic technology alliances. Technovation, 24(7), 563-571. https://doi.org/10.1016/S0166-4972(02)00123-2

Vlegels, J., \& Huisman, J. (2021). The emergence of the higher education research field (1976-2018): Preferential attachment, smallworldness and fragmentation in its collaboration networks. Higher Education, 81(5), 1079-1095. https://doi.org/10.1007/s10734-020-00600-8

Wasserman, S., \& Faust, K. (1994). Social network analysis: Methods and applications (Vol. 8). Cambridge University Press.

Watts, D. J., \& Strogatz, S. H. (1998). Collective dynamics of "small-world" networks. Nature, 393(6684), 440-442. https://doi.org/10.1038/30918

Wolfe, R. A. (1994). Organizational innovation: Review, critique and suggested research directions. Journal of Management Studies, 31(3), 405-431. https://doi.org/10.1111/j.1467-6486.1994.tb00624.x

Publisher's Note Springer Nature remains neutral with regard to jurisdictional claims in published maps and institutional affiliations. 